\title{
Peripheral Arterial Disease in Women: an Overview of Risk Factor Profile, Clinical Features, and Outcomes
}

\author{
Qurat-ul-ain Jelani $^{1} \cdot$ Mikhail Petrov $^{2} \cdot$ Sara C. Martinez $^{3} \cdot$ Lene Holmvang $^{4} \cdot$ Khaled Al-Shaibi $^{5} \cdot$ Mirvat Alasnag $^{5}$
}

Published online: 2 June 2018

(C) The Author(s) 2018

\begin{abstract}
Purpose of Review Peripheral arterial disease (PAD) is the third most common manifestation of cardiovascular disease (CVD), following coronary artery disease (CAD) and stroke. PAD remains underdiagnosed and under-treated in women.

Recent Findings Women with PAD experience more atypical symptoms and poorer overall health status. The prevalence of PAD in women increases with age, such that more women than men have PAD after the age of 40 years. There is under-representation of PAD patients in clinical trials in general and women in particular. In this article, we address the lack of women participants in PAD trials. We then present a comprehensive overview of the epidemiology/risk factor profile, clinical features, treatment, and outcomes. Summary PAD is prevalent in women and its global burden is on the rise despite a decline in global age-standardized death rate from CVD. The importance of this issue has been underlined by the American Heart Association's (AHA) "Call to Action" scientific statement on PAD in women. Large-scale campaigns are needed to increase awareness among physicians and the general public. Furthermore, effective treatment strategies must be implemented.
\end{abstract}

Keywords Peripheral arterial disease $\cdot$ Women $\cdot$ Sex differences

\section{Background}

Peripheral arterial disease (PAD) remains a significant health concern across the globe. As of 2010, more than 200 million people worldwide are living with PAD, representing a $29 \%$ increased prevalence in low-middle income countries and $13 \%$ increase in high income countries $[1,2]$. In the USA

This article is part of the Topical Collection on Women and Ischemic Heart Disease

Mirvat Alasnag

mirvat@jeddacath.com

1 Department of Cardiology, Bridgeport Hospital, Yale New Haven Health, New Haven, CT, USA

2 Department of Internal Medicine, Norwalk Hospital, Norwalk, CT, USA

3 Division of Cardiology, Providence St. Peter Hospital, Olympia, WA, USA

4 Department of Cardiology, Rigshospitalet, Copenhagen University Hospital, Copenhagen, Denmark

5 Cardiac Center, King Fahd Armed Forces Hospital, Jeddah, Saudi Arabia alone, PAD affects 8 million Americans aged $>40$ years [3]. In the Reduction of Atherothrombosis for Continued Health (REACH) Registry, the cumulative end point of major cardiovascular events, vascular interventions, and hospitalization was significantly higher in patients with PAD than patients with coronary artery disease (CAD) [4]. PAD is associated with equal morbidity and mortality and economic costs as $\mathrm{CAD}$ and ischemic stroke $[5,6]$. In a scientific statement on Women and PAD from the AHA in 2012 [7], Hirsch et al. noted the increased prevalence of PAD in adults $\geq 40$ years of age, and highlighted the need for raising clinical awareness, focused treatment plans, and expanding research on PAD in women. Women have higher rates of asymptomatic/ subclinical disease and the majority have atypical symptoms. They also have a poorer overall health status. Women with PAD suffer more from depression compared to women without PAD [8-15, 16•].

Overall, there is limited recruitment of patients with PAD in cardiovascular trials, especially women, minorities, and the elderly [17•]. For the purpose of this review, we will focus on the different aspects of PAD in women including data on representation in research studies, epidemiology, clinical features, and outcomes. 


\section{Representation of Women in PAD Studies}

Sex differences in PAD have been reported not only in prevalence, diagnosis, and clinical presentation but also in outcomes. Women continue to have variable enrollment in studies on PAD (Table 1 and Fig. 1). In more than half of these studies, women comprise $<35 \%$ of the whole study population. In the Nation Wide inpatient sample of patients with PAD, women comprised $41 \%$ of the study population. However, in randomized control trials (RCT) of vascular surgery, women represented only $22 \%$ [18]. In a systematic review of cardiovascular trials, which collectively enrolled 412,048 patients, only $27 \%$ of the total population were women [17•]. While enrollment of women has increased overall in clinical trials, it continues to lag behind their overall representation in this disease [19•].

\section{Epidemiology and Risk Factors}

Women with PAD present on average 10-20 years later than men [20]. Around $20-30 \%$ of women aged 70 years or older are affected by PAD [21, 22]. This is hypothesized to be secondary to the loss of the vascular protective effects of estrogen which promotes vasodilation and has anti-oxidative effects. In a study of $>370,000$ surgical inpatients with PAD, Vouyouka et al. found that women were more likely to be older, obese, and black [23•]. Overall risk factors for PAD remain similar among men and women, including smoking, age, diabetes mellitus, hypertension, and dyslipidemia [3]. Diabetes and hyperlipidemia have been shown to increase the risk of intermittent claudication by fourfold in women [24, 25]. Importantly, ethnic differences have been shown to affect the prevalence of PAD as well, with the highest prevalence of PAD among non-Hispanic black women over the age of 70 (25\%) [26•]. Other studies have shown association between obesity [27], levels of C-reactive protein (CRP) [28, 29], osteopenia/osteoporosis [30, 31], hypothyroidism, and PAD. In the Multiethnic Study of Atherosclerosis (MESA) [29], women had higher levels of CRP than men, after adjustment for comorbidities, hormonal status, and age. Conflicting data has emerged for the association between hormone replacement therapy and PAD in women. In the Women Health Initiative (WHI) and Heart and Estrogen/Progestin replacement (HERS) studies, no benefit was observed from HRT use for PAD or CAD. Conversely, the Rotterdam study showed a $52 \%$ decreased risk of PAD in women who used HRT for $>1$ year [32-34]. Interestingly, vascular complications associated with pregnancy have also been associated with an increased risk of PAD. The Cardiovascular Health After Maternal Placental Syndrome (CHAMPS) study showed a threefold increased risk of PAD and twofold increased risk of coronary artery and cerebrovascular disease in patients with maternal placental syndromes, including pre-eclampsia, gestational hypertension, placental abruption, and placental infarction [35]. The mechanisms for this association are unclear, although one likely hypothesis is underlying endothelial dysfunction.

The treatment of risk factors varies by gender. In the REACH registry [4], consisting of $>68,000$ outpatients, risk factor control was less frequently observed in patients with diagnosis of PAD. Optimal risk factor control was twice as likely for men than women despite a higher incidence of diabetes, hypertension, and elevated total cholesterol in women.

\section{Symptoms}

Both men and women present with typical, atypical, or asymptomatic PAD. Studies have shown that the majority of PAD patients do not have typical claudication $[11,36]$. Asymptomatic disease is defined as absence of exertional leg symptoms in the presence of an ankle-brachial index $(\mathrm{ABI})<0.90$, while atypical symptoms are defined by leg symptoms present at rest and exercise [37, 38]. In the Women Health and Aging study (WHAS), of the 933 women enrolled, 35\% ( $n=328)$ had an ABI of 0.90; of these, 328 patients $(63 \%)$ had no exertional leg symptoms [39]. Importantly, asymptomatic PAD has been shown to be more common in women than in men (13 vs 9\%; $p<0.03)$ [40]. When symptomatic, women seek medical attention with more complex (multilevel) and severe disease including critical limb ischemia (CLI) [16•, 40, 41]. In patients with CLI, women had a twofold higher incidence of femoropopliteal disease compared to men [42]. This finding was reproduced in another patient cohort undergoing angioplasty that showed pronounced femoropopliteal disease in women while men had more below-the-knee disease [43]. Additionally, women have greater lower extremity functional impairment [8], with shorter treadmill distance to intermittent claudication [44], shorter maximal treadmill walking distance $[8,44]$, and poorer quality of life scores compared to men [45]. Other studies have demonstrated a higher prevalence of asymptomatic disease in women, which may lead to a late presentation, thus contributing to severe disease or CLI [41].

\section{Treatment}

The principle components of PAD treatment consist of supervised exercise therapy, pharmacological treatment, and lower extremity revascularization. Patients with PAD are less likely to receive guideline-directed medical therapy (GDMT) than are patients with other forms of cardiovascular disease, including CAD [46-48]. For example, in one study on secondary prevention of PAD, statin use was reported in only $31 \%$, angiotensin- 


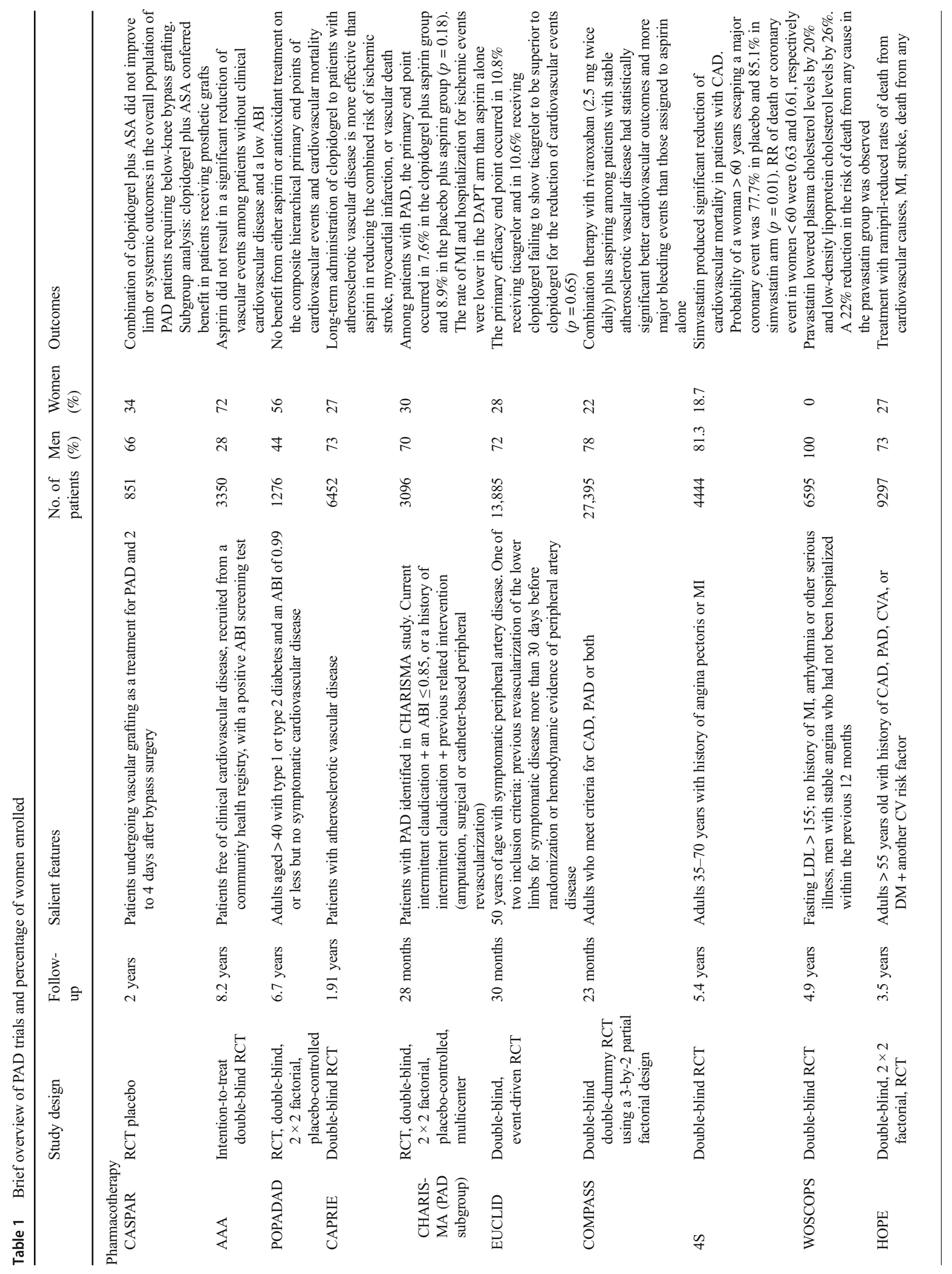




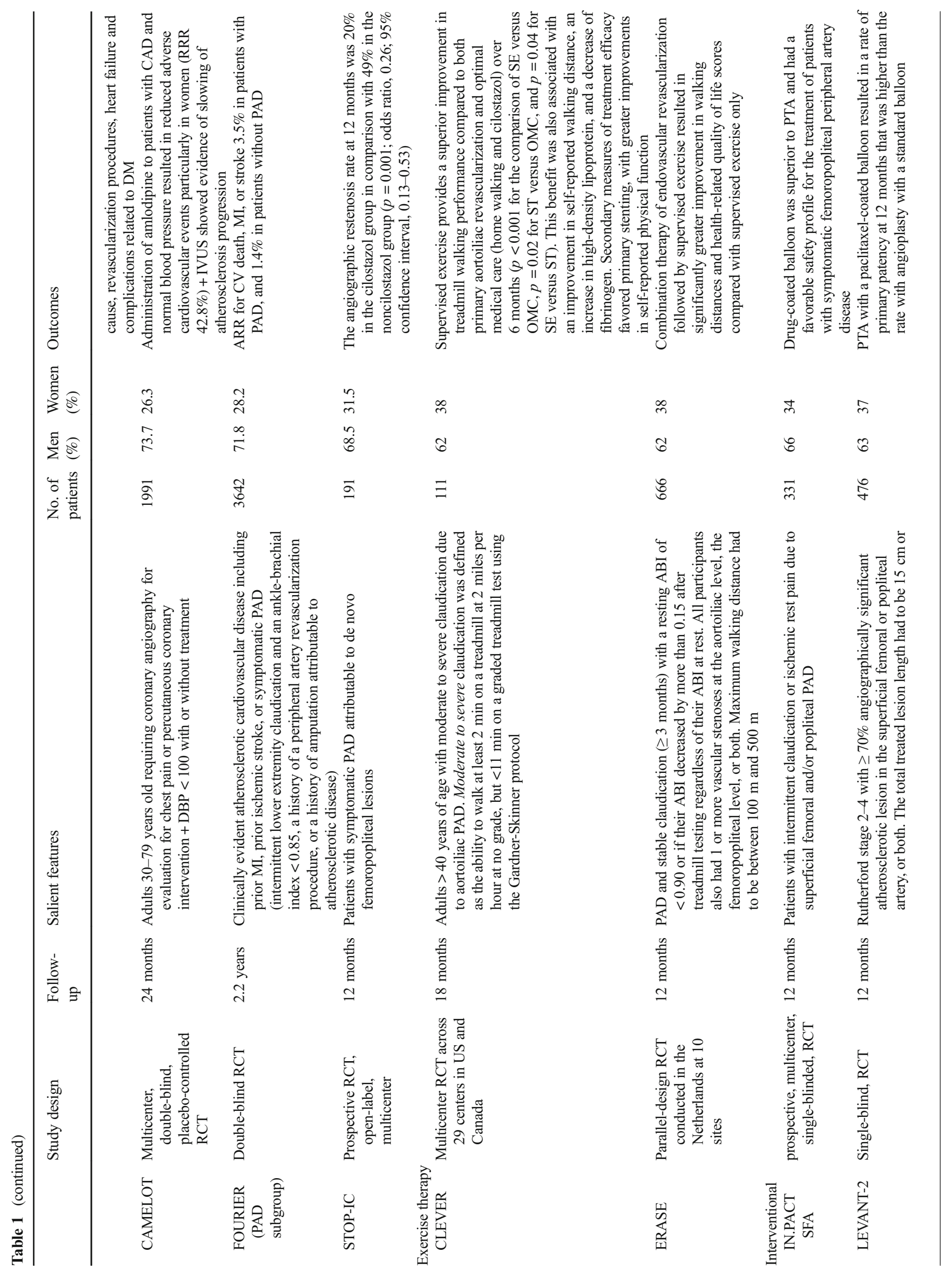



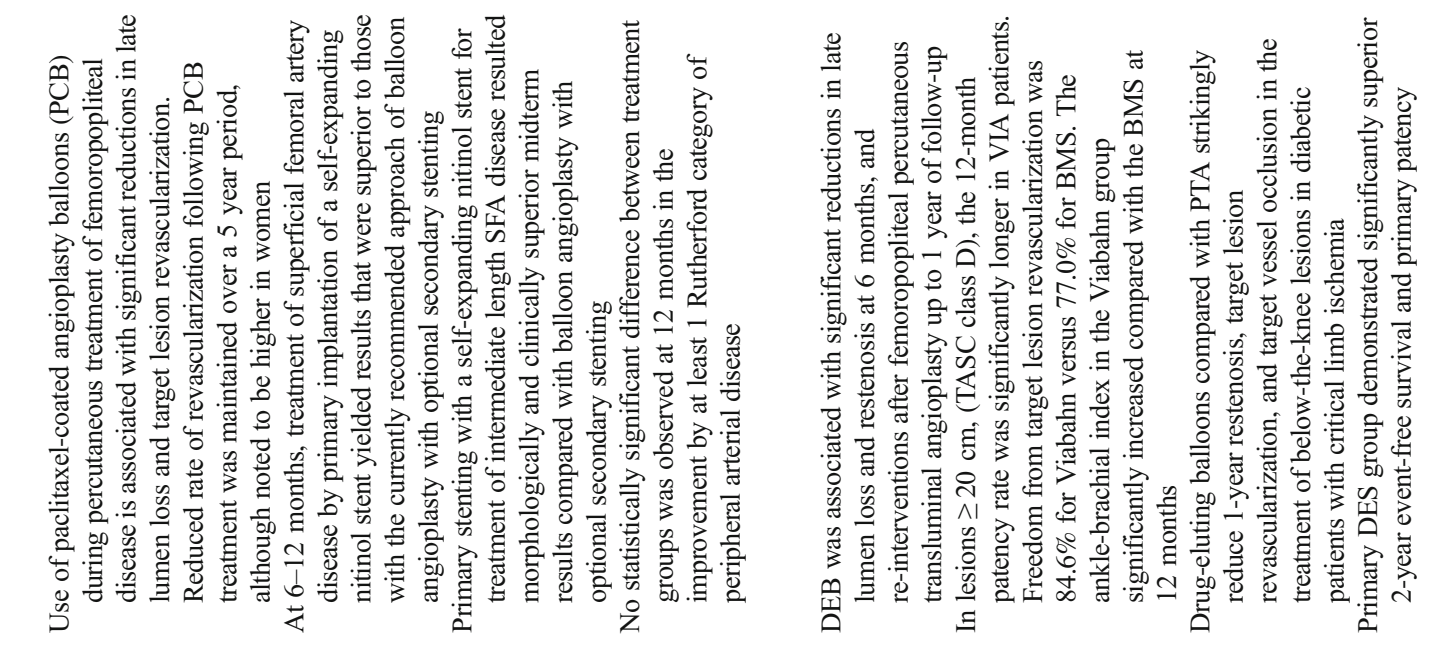

\begin{tabular}{|c|c|c|c|}
\hline$\stackrel{ن}{m}$ & f & లె & $\bar{m}$ \\
\hline $\begin{array}{l}n \\
\vdots \\
n\end{array}$ & $\tilde{n}$ & 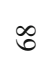 & 8 \\
\hline 苞 & $\stackrel{t}{\subseteq}$ & $\cong$ & $\underset{\sim}{J}$ \\
\hline
\end{tabular}

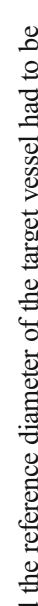

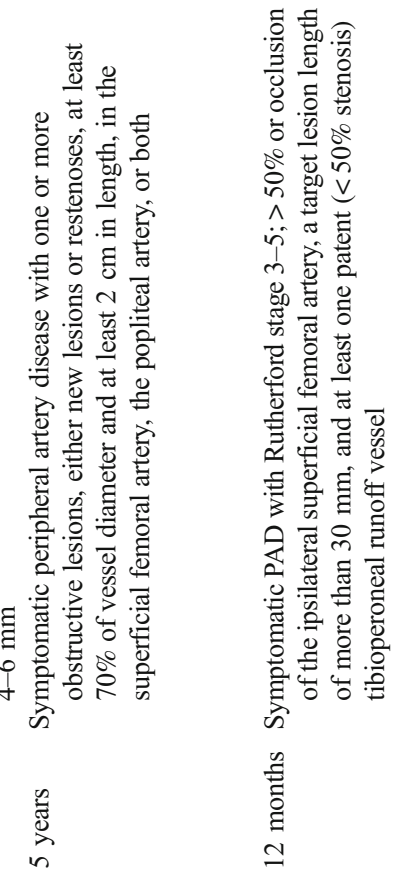

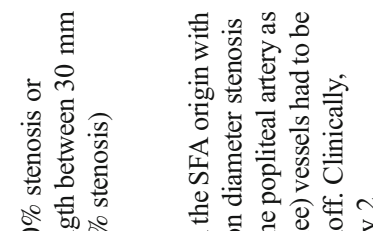

ซ

in $F$

กิ

$\infty \quad \exists$

$\infty$

$\stackrel{2}{\stackrel{+}{+}}$

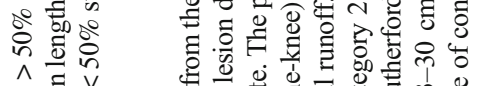

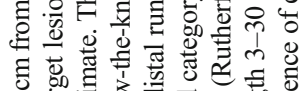

क.

离范

吾焉

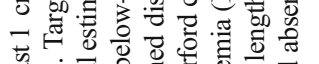

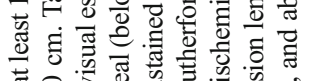

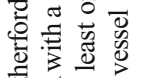

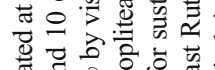

눙

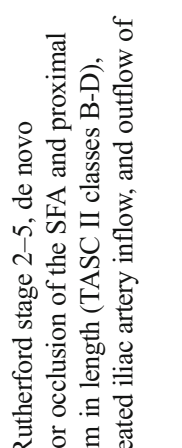

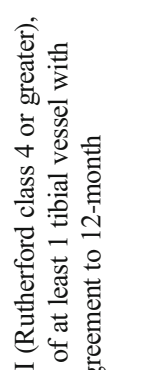

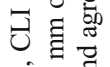

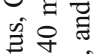

岕-总

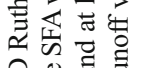

论

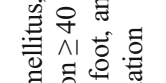

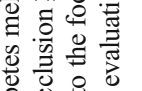

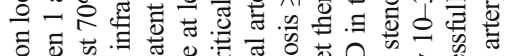

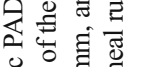

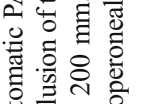

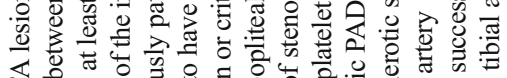

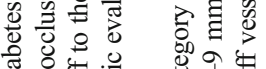

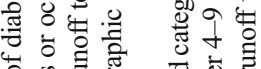

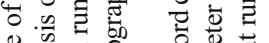

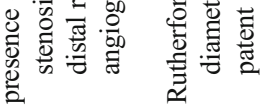

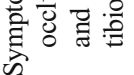

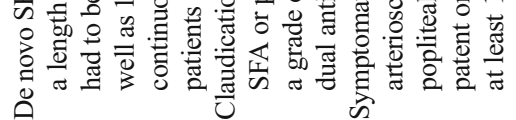

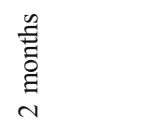

胥

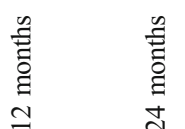

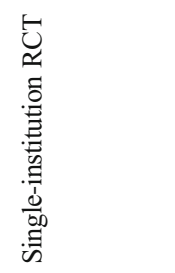

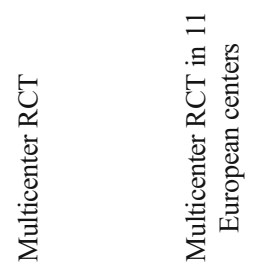

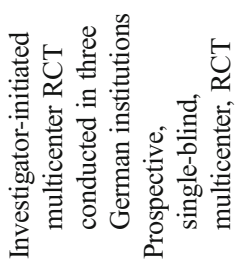

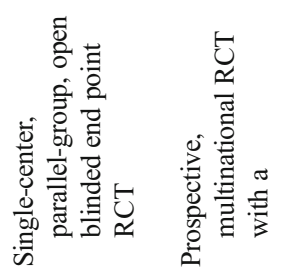

状

$z$
0
$\frac{\pi}{4}$

蒙

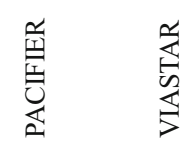

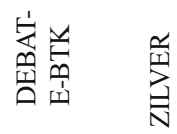




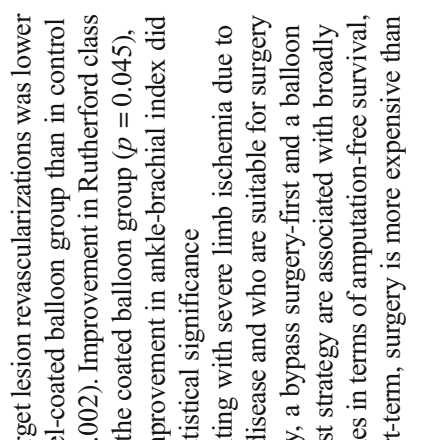

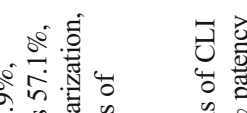

द्वे

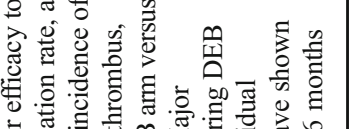

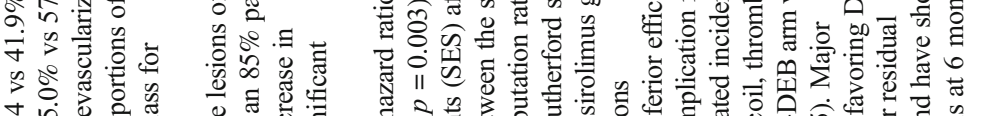

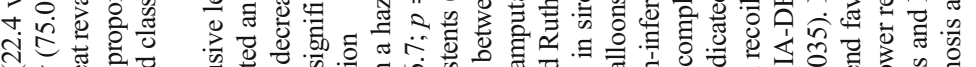

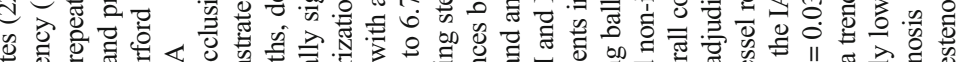

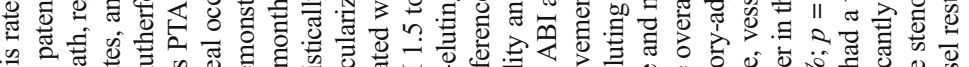

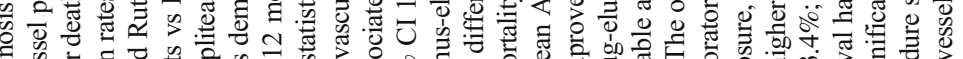

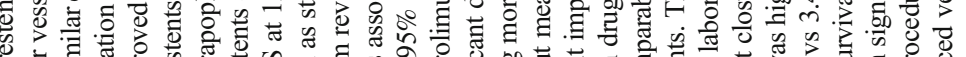

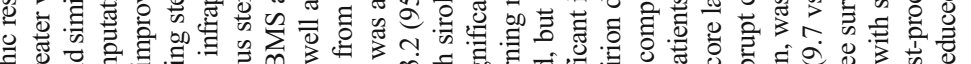

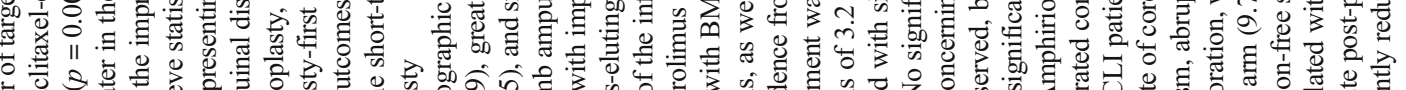

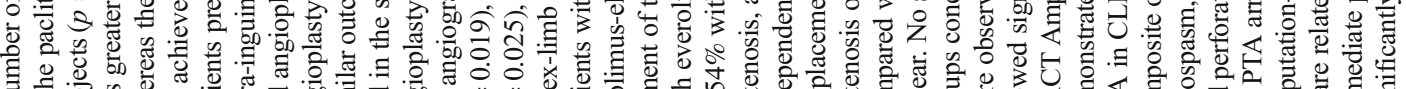

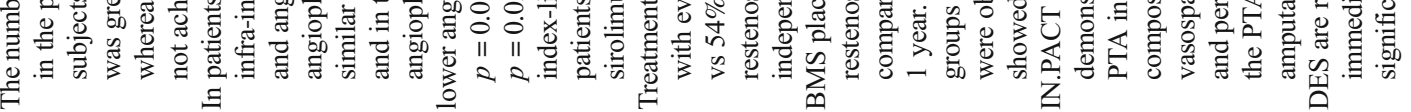

है

$\begin{array}{ll} & n \\ 8 & \stackrel{+}{7} \\ 8 & n\end{array}$

n.

$\stackrel{n}{*}$

n.

$\sum^{\frac{0}{2}} \mathrm{~g}$

$\grave{\infty}$

䆘

ฉั

กิ

$n$
$m$
$m$
0
0

ฉू.

$\stackrel{+}{m}$

ष

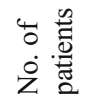

总

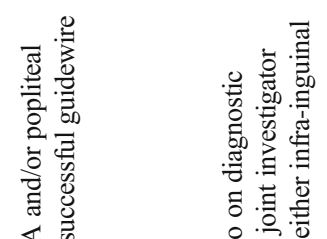

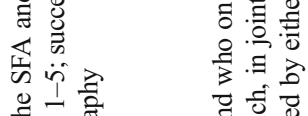

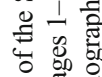

焉害焉

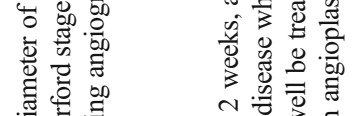

矛要.具

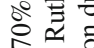

시류에

$\hat{0}$ 范

究表嵒言

要

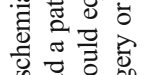

离

商部

可

直.

离. 苛言

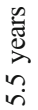

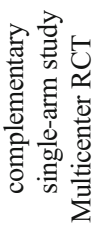

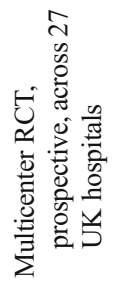

ฉั

营

옴

$\underline{\square}$

$\infty$

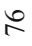

in

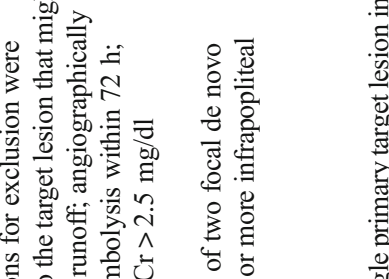

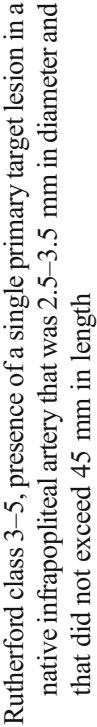

区्ञ

:

을 을

空畐

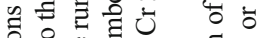

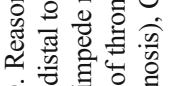

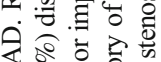

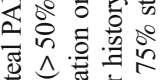

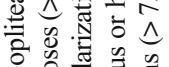

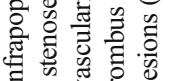

彭要焉

言 。

晃

옹

章

造

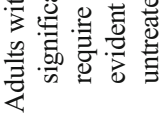

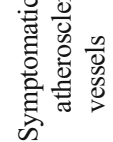

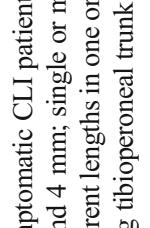

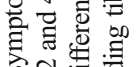

क人त 융

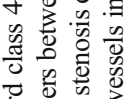

可喓

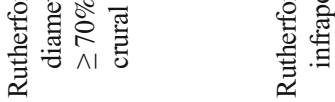

言 咅

党

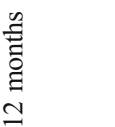

气્๋

言

章

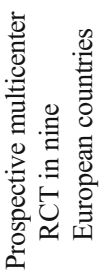

工

บ

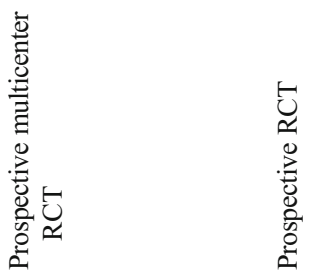

脐

悹

毁

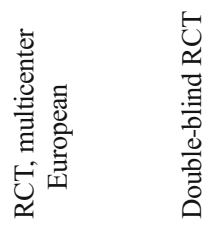

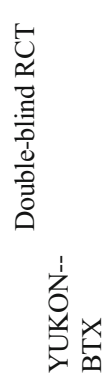

ֶֻ.

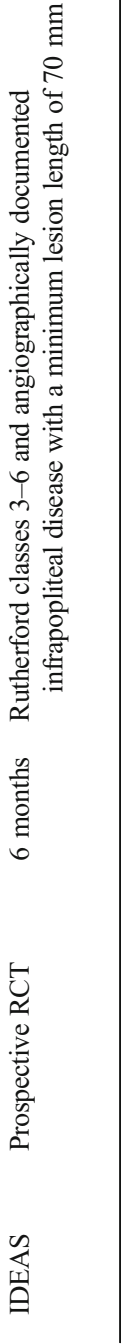


Fig. 1 Trends and \% women in cardiovascular clinical trials 1994-2017
Trends and \% Women in Cardiovascular Clinical Trials 1994-2017

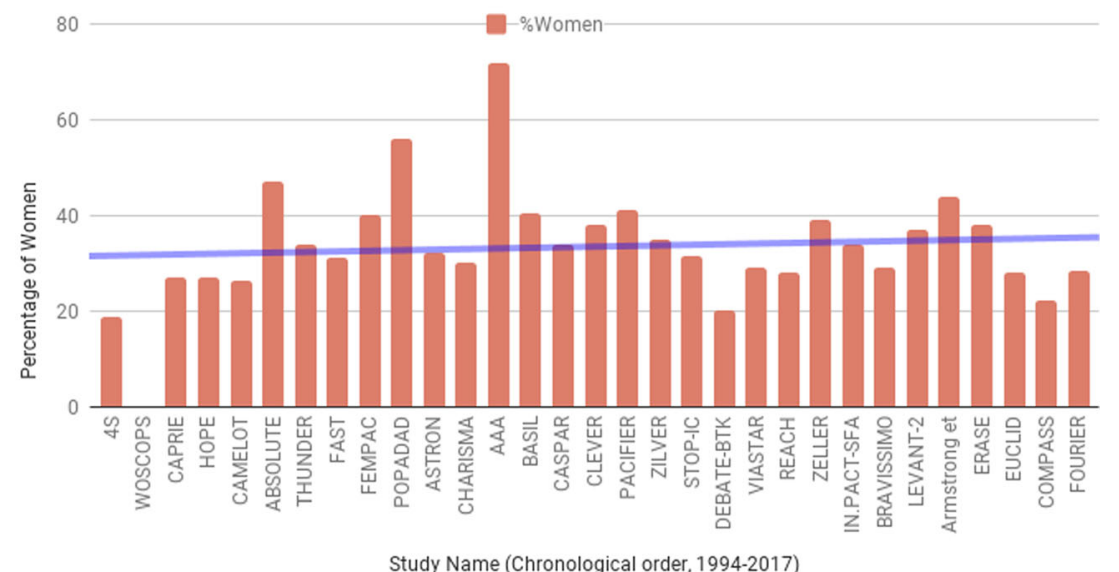

converting enzyme inhibitor use in $25 \%$, and aspirin use in $36 \%$ [48]. Data also exists on suboptimal use of systemic vascular treatment or lack of adherence to standard therapy. In the NHANES study, only 24-34\% adherence to preventive therapy was reported [48]. CHAMPS study cited similar suboptimal use of GDMT but was particularly notable for lower rates in women and older patients [31]. In terms of intensity of treatment with standard pharmacologic agents, men were more likely to receive all agents (antiplatelets, statins, and angiotensin enzyme inhibitors) than women (22.4 vs $18.2 \%$ ) [31]. This finding was reproduced in another study from Quebec which showed that men were more likely to receive statins, antiplatelet agents, and angiotensin-converting enzyme inhibitors than women (22.4 vs $18.2 \%, p<0.001)$ [31].

Patients with PAD experience a profound limitation in exercise performance. There is evidence of a well-established benefit following a typical 12 -week exercise training program $[49,50]$. Lower extremity exercise training has been shown to increase time to claudication, increase distance before claudication, and increase overall walking distance [51]. Unfortunately, women with PAD have been shown to be less responsive to exercise rehabilitation programs [52], particularly diabetic women. This may partly be due to a greater impairment in calf muscle oxygen saturation during and following exercise [53]. Gardner et al. reported that improvements in absolute walking distance were significantly less for women than men after 1 year of standard exercise therapy. Women also reported less subjective improvement on walking impairment questionnaire domains [54]. These differences have been attributed to lower hemoglobin saturation during ambulation [53], poorer leg strength [55], higher inflammation, higher level of oxidative stress, and insulin resistance [53].

Endovascular revascularization and open bypass surgery are two strategies for disabling claudication after failure of medical therapy or for those with CLI. Although the choice of procedure depends on many lesion characteristics including lesion site $[56,57]$, the 2016 AHA/ACC Guidelines recommend an endovascular approach first for both lifestyle limiting claudication and CLI. While data has been equivocal, sex differences have also been reported in lower extremity endovascular versus bypass treatment. Using 69 million discharge records from the Nationwide Inpatient Sample from 1998 to 2006, Roe et al. reported discrepancies in the proportion of endovascular procedures being performed in women compared to men. Women were less likely to undergo amputation or open vascular surgery than men. Women, however, were more likely to undergo an endovascular procedure during hospitalization $[58,59]$. Several possible reasons have been cited for lower bypass rates, including the observation that women with PAD are generally older with more advanced disease, comorbidities, and may have smaller vessel size precluding bypass.

\section{Carotid Artery Stenosis and Management}

Women have a greater risk of disabling stroke (58 vs 48\%) and stroke-related mortality (20 vs 14\%) [60]. Strokerelated mortality has not changed over the past 50 years in women and is attributed to older age at onset of stroke among women [60]. Multiple trials have demonstrated a reduction in the risk of stroke in select patients with symptomatic internal carotid artery disease and to a lesser extent, in those with asymptomatic carotid artery disease [61-63]. However, it is noteworthy that women comprised only 28 $34 \%$ of enrolled patients in these trials. In an analysis of the North American Symptomatic Carotid Endarterectomy Trial (NASCET) and ACAS trial, 30-day risk for death was higher in women than in men $(2.3$ vs $0.8 \%, p=$ 0.002 ), owing to higher risk of fatal stroke [64]. Both men and women benefited from carotid endarterectomy (CEA) for stroke prevention. However, in another study, the risk of stroke or death within 30 days after CEA in symptomatic patients was greater in women $(8.7 \%)$ vs men $(6.8 \%)$ [65], a 
finding which was reproduced in a systematic review of 36 studies [66]. However, other studies have shown no significant difference in complications and mortality following CEA [67, 68]. Regarding carotid artery stenting, women have worse outcomes, including higher rates of in-hospital mortality and stroke [69]. Risk of stroke or mortality was 1.7-fold higher in symptomatic women and 3.4-fold higher in asymptomatic women with carotid artery stenosis (CAS) compared to CEA. Asymptomatic women experienced worse outcomes compared to men, with higher stroke rates after CEA and higher myocardial infarction rates after both CEA and CAS [70].

\section{Quality of Life}

Quality of life scores have become an important tool to assess treatment effectiveness in the general population. Multiple studies have shown worse health status and health-related quality of life in women when compared with men suffering from PAD $[10,12,13]$. In addition, functional status has been determined to be significantly lower for women [45]. This was associated with greater mood disturbances [12]. Female gender has been adversely associated with durability of the revascularization or the quality of life following revascularization for claudication or CLI [71]. In a longitudinal study of a large PAD population, women with PAD were found to have compromised health status both at diagnosis and 12 months after follow-up. The mechanism for poor health status in these women was thought to be associated with lower education and lack of social support (women were less likely to have a partner) [72].

\section{Outcomes/Prognosis}

Outcome trials of endovascular or surgical revascularization in men and women have reported conflicting results. Several studies have reported an unfavorable impact of sex on outcomes after peripheral revascularization procedures Women tend to have higher perioperative mortality whether undergoing surgical or endovascular procedures [73, 74]. Furthermore, they have inferior patency rates after surgical revascularization [75-77], higher risk of stent thrombosis with endovascular revascularization [77], wound complications [78], and bleeding events [23•]. On the other hand, multiple other studies, including some systematic reviews, have found no sex difference in patency rates and amputation-free survival [79-81].

PAD is associated with increased risk of CVD mortality and morbidity. A low ABI $(\leq 0.9)$ is associated with a threefold increased risk of all-cause mortality and cardiovascular mortality in both men and women [82]. Women with PAD have a two- to fourfold increased risk of cardiovascular mortality and morbidity compared to women without PAD [15].
Compared to men, women are more likely to be admitted for acute myocardial infarction [83], more likely to be admitted emergently with longer hospital stays and more likely to require rehabilitation or nursing home care [16•, 59, 84]. Similarly, women with CLI have higher in-hospital mortality after both endovascular treatments and open surgery [85].

\section{Conclusions}

PAD remains a major healthcare problem. It remains underdiagnosed and understudied in women. The major challenge in PAD treatment in women is their late presentation and the higher prevalence of asymptomatic disease which may lead to more advanced disease at presentation and a higher risk of adverse events and mortality. Concerted research efforts should be carried out to further determine the effects of sex on different aspects of PAD including risk factors, clinical burden, treatment, and outcomes. In addition, campaigns to raise awareness among clinicians and the general public should be undertaken. Efforts along the lines of the "National Wear Red Day" campaign by the AHA should be pursued aggressively to increase awareness.

\section{Compliance with Ethical Standards}

Conflict of Interest Qurat-ul-ain Jelani, Mikhail Petrov, Sara C. Martinez, Lene Holmvang, Khaled Al-Shaibi, and Mirvat Alasnag declare that they have no conflict of interest.

Human and Animal Rights and Informed Consent This article does not contain any studies with human or animal subjects performed by any of the authors.

Open Access This article is distributed under the terms of the Creative Commons Attribution 4.0 International License (http:// creativecommons.org/licenses/by/4.0/), which permits unrestricted use, distribution, and reproduction in any medium, provided you give appropriate credit to the original author(s) and the source, provide a link to the Creative Commons license, and indicate if changes were made.

\section{References}

Papers of particular interest, published recently, have been highlighted as:

- Of importance

1. Fowkes FG, Rudan D, Rudan I, Aboyans V, Denenberg JO, McDermott MM, et al. Comparison of global estimates of prevalence and risk factors for peripheral artery disease in 2000 and 2010: a systematic review and analysis. Lancet. 2013;382(9901): 1329-40. https://doi.org/10.1016/S0140-6736(13)61249-0.

2. Sampson UK, Fowkes FG, McDermott MM, Criqui MH, Aboyans $\mathrm{V}$, Norman PE, et al. Global and regional burden of death and disability from peripheral artery disease: 21 world regions, 1990 
to 2010. Glob Heart. 2014;9(1):145-58 e21. https://doi.org/10. 1016/j.gheart.2013.12.008.

3. Lloyd-Jones D, Adams R, Carnethon M, De Simone G, Ferguson TB, Flegal K, et al. Heart disease and stroke statistics - 2009 update: a report from the American Heart Association Statistics Committee and Stroke Statistics Subcommittee. Circulation. 2009;119(3):480-6. https://doi.org/10.1161/CIRCULATIONAHA.108.191259.

4. Steg PG, Bhatt DL, Wilson PW, D’Agostino R Sr, Ohman EM, Rother J, et al. One-year cardiovascular event rates in outpatients with atherothrombosis. JAMA. 2007;297(11):1197-206. https:// doi.org/10.1001/jama.297.11.1197.

5. Mahoney EM, Wang K, Cohen DJ, Hirsch AT, Alberts MJ, Eagle $\mathrm{K}$, et al. One-year costs in patients with a history of or at risk for atherothrombosis in the United States. Circ Cardiovasc Qual Outcomes. 2008;1(1):38-45. https://doi.org/10.1161/ CIRCOUTCOMES.108.775247.

6. Hirsch AT, Hartman L, Town RJ, Virnig BA. National health care costs of peripheral arterial disease in the Medicare population. Vasc Med. 2008;13(3):209-15. https://doi.org/10.1177/1358863X08089277.

7. Hirsch AT, Allison MA, Gomes AS, Corriere MA, Duval S, Ershow AG, et al. A call to action: women and peripheral artery disease: a scientific statement from the American Heart Association. Circulation. 2012;125(11):1449-72. https://doi.org/10.1161/CIR. 0b013e31824c39ba

8. McDermott MM, Greenland P, Liu K, Criqui MH, Guralnik JM, Celic L, et al. Sex differences in peripheral arterial disease: leg symptoms and physical functioning. J Am Geriatr Soc. 2003;51(2):222-8.

9. Safley DM, House JA, Laster SB, Daniel WC, Spertus JA, Marso SP. Quantifying improvement in symptoms, functioning, and quality of life after peripheral endovascular revascularization. Circulation. 2007;115(5):569-75. https://doi.org/10.1161/ CIRCULATIONAHA.106.643346.

10. Mastenbroek MH, Hoeks SE, Pedersen SS, Scholte Op Reimer WJ, Voute MT, Verhagen HJ. Gender disparities in disease-specific health status in postoperative patients with peripheral arterial disease. Eur J Vasc Endovasc Surg. 2012;43(4):433-40. https://doi. org/10.1016/j.ejvs.2011.12.022.

11. McDermott MM, Mehta S, Greenland P. Exertional leg symptoms other than intermittent claudication are common in peripheral arterial disease. Arch Intern Med. 1999;159(4):387-92.

12. Oka RK, Szuba A, Giacomini JC, Cooke JP. Gender differences in perception of PAD: a pilot study. Vasc Med. 2003;8(2):89-94. https://doi.org/10.1191/1358863x03vm479oa.

13. Bloemenkamp DG, Mali WP, Tanis BC, van den Bosch MA, Kemmeren JM, Algra A, et al. Functional health and well-being of relatively young women with peripheral arterial disease is decreased but stable after diagnosis. J Vasc Surg. 2003;38(1):104-10.

14. Smolderen KG, Spertus JA, Vriens PW, Kranendonk S, Nooren M, Denollet J. Younger women with symptomatic peripheral arterial disease are at increased risk of depressive symptoms. J Vasc Surg. 2010;52(3):637-44. https://doi.org/10.1016/j.jvs.2010.04.025.

15. Higgins JP, Higgins JA. Epidemiology of peripheral arterial disease in women. J Epidemiol. 2003;13(1):1-14.

16. Jackson EA, Munir K, Schreiber T, Rubin JR, Cuff R, Gallagher $\mathrm{KA}$, et al. Impact of sex on morbidity and mortality rates after lower extremity interventions for peripheral arterial disease: observations from the Blue Cross Blue Shield of Michigan Cardiovascular Consortium. J Am Coll Cardiol. 2014;63(23):2525-30. https:// doi.org/10.1016/j.jacc.2014.03.036. This directly addresses the impact of sex on MACE. Even though it examines a very limited population, Michigan, it identifies a difference in mortalilty and morbidity based on sex

17. Vyas MV, Mrkobrada M, Donner A, Hackam DG. Underrepresentation of peripheral artery disease in modern cardiovascular trials: systematic review and meta-analysis. Int J Cardiol.
2013;168(5):4875-6. https://doi.org/10.1016/j.ijcard.2013.07. 050 . This article notes that peripheral vascular disease is understudied in most recent cardiovascular trials

18. Hoel AW, Kayssi A, Brahmanandam S, Belkin M, Conte MS, Nguyen LL. Under-representation of women and ethnic minorities in vascular surgery randomized controlled trials. J Vasc Surg. 2009;50(2):349-54. https://doi.org/10.1016/j.jvs.2009.01.012.

19. Melloni C, Berger JS, Wang TY, Gunes F, Stebbins A, Pieper KS, et al. Representation of women in randomized clinical trials of cardiovascular disease prevention. Circ Cardiovasc Qual Outcomes. 2010;3(2):135-42. https://doi.org/10.1161/CIRCOUTCOMES. 110.868307. This article notes that women are understudied in most cardiovascular trials in general

20. Nguyen L, Liles DR, Lin PH, Bush RL. Hormone replacement therapy and peripheral vascular disease in women. Vasc Endovasc Surg. 2004;38(6):547-56. https://doi.org/10.1177/ 153857440403800609 .

21. Newman AB, Siscovick DS, Manolio TA, Polak J, Fried LP, Borhani $\mathrm{NO}$, et al. Ankle-arm index as a marker of atherosclerosis in the Cardiovascular Health Study. Cardiovascular Heart Study (CHS) collaborative research group. Circulation. 1993;88(3):837-45.

22. Criqui MH, Fronek A, Barrett-Connor E, Klauber MR, Gabriel S, Goodman D. The prevalence of peripheral arterial disease in a defined population. Circulation. 1985;71(3):510-5.

23. Vouyouka AG, Egorova NN, Salloum A, Kleinman L, Marin M, Faries PL, et al. Lessons learned from the analysis of gender effect on risk factors and procedural outcomes of lower extremity arterial disease. J Vasc Surg. 2010;52(5):1196-202. https://doi.org/10. 1016/j.jvs.2010.05.106. This article highlights the difference in procedural outcomes in women. It notes that a difference does exist even when accounting for risk factors as confounding variables

24. Gerhard M, Baum P, Raby KE. Peripheral arterial-vascular disease in women: prevalence, prognosis, and treatment. Cardiology. 1995;86(4):349-55.

25. Kannel WB, McGee DL. Update on some epidemiologic features of intermittent claudication: the Framingham study. J Am Geriatr Soc. 1985;33(1):13-8.

26. Eraso LH, Fukaya E, Mohler ER 3rd, Xie D, Sha D, Berger JS. Peripheral arterial disease, prevalence and cumulative risk factor profile analysis. Eur J Prev Cardiol. 2014;21(6):704-11. https:// doi.org/10.1177/2047487312452968. This article notes examines peripheral vascular disease in general in terms of risk factors and prevalence. Surprisingly, there is paucity of this kind of basic data

27. Lu B, Zhou J, Waring ME, Parker DR, Eaton CB. Abdominal obesity and peripheral vascular disease in men and women: a comparison of waist-to-thigh ratio and waist circumference as measures of abdominal obesity. Atherosclerosis. 2010;208(1):253-7. https:// doi.org/10.1016/j.atherosclerosis.2009.06.027.

28. Ridker PM, Cushman M, Stampfer MJ, Tracy RP, Hennekens CH. Plasma concentration of C-reactive protein and risk of developing peripheral vascular disease. Circulation. 1998;97(5):425-8.

29. Lakoski SG, Cushman M, Criqui M, Rundek T, Blumenthal RS, D'Agostino RB Jr, et al. Gender and C-reactive protein: data from the Multiethnic Study of Atherosclerosis (MESA) cohort. Am Heart J. 2006;152(3):593-8. https://doi.org/10.1016/j.ahj.2006.02.015.

30. Aronow WS. Osteoporosis, osteopenia, and atherosclerotic vascular disease. Arch Med Sci. 2011;7(1):21-6. https://doi.org/10.5114/ aoms.2011.20599.

31. Paquet M, Pilon D, Tetrault JP, Carrier N. Protective vascular treatment of patients with peripheral arterial disease: guideline adherence according to year, age and gender. Can J Public Health. 2010;101(1):96-100.

32. Rossouw JE, Prentice RL, Manson JE, Wu L, Barad D, Barnabei $\mathrm{VM}$, et al. Postmenopausal hormone therapy and risk of 
cardiovascular disease by age and years since menopause. JAMA. 2007;297(13):1465-77. https://doi.org/10.1001/jama.297.13.1465.

33. Grady D, Herrington D, Bittner V, Blumenthal R, Davidson M, Hlatky M, et al. Cardiovascular disease outcomes during 6.8 years of hormone therapy: Heart and Estrogen/Progestin Replacement Study follow-up (HERS II). JAMA. 2002;288(1):49-57.

34. Hsia J, Simon JA, Lin F, Applegate WB, Vogt MT, Hunninghake D, et al. Peripheral arterial disease in randomized trial of estrogen with progestin in women with coronary heart disease: the Heart and Estrogen/Progestin Replacement Study. Circulation. 2000;102(18):2228-32.

35. Ray JG, Vermeulen MJ, Schull MJ, Redelmeier DA. Cardiovascular health after maternal placental syndromes (CHAMPS): population-based retrospective cohort study. Lancet. 2005;366(9499):1797-803. https://doi.org/10.1016/S01406736(05)67726-4

36. Hirsch AT, Criqui MH, Treat-Jacobson D, Regensteiner JG, Creager MA, Olin JW, et al. Peripheral arterial disease detection, awareness, and treatment in primary care. JAMA. 2001;286(11): 1317-24.

37. Hirsch AT, Hiatt WR, Committee PS. PAD awareness, risk, and treatment: new resources for survival-the USA PARTNERS program. Vasc Med. 2001;6(3 Suppl):9-12. https://doi.org/10.1177/ 1358836X0100600i103.

38. McDermott MM, Greenland P, Liu K, Guralnik JM, Criqui MH, Dolan NC, et al. Leg symptoms in peripheral arterial disease: associated clinical characteristics and functional impairment. JAMA. 2001;286(13):1599-606.

39. McDermott MM, Fried L, Simonsick E, Ling S, Guralnik JM. Asymptomatic peripheral arterial disease is independently associated with impaired lower extremity functioning: the women's health and aging study. Circulation. 2000;101(9):1007-12.

40. Sigvant B, Wiberg-Hedman K, Bergqvist D, Rolandsson O, Andersson B, Persson E, et al. A population-based study of peripheral arterial disease prevalence with special focus on critical limb ischemia and sex differences. J Vasc Surg. 2007;45(6):1185-91. https://doi.org/10.1016/j.jvs.2007.02.004.

41. Brevetti G, Bucur R, Balbarini A, Melillo E, Novo S, Muratori I, et al. Women and peripheral arterial disease: same disease, different issues. J Cardiovasc Med (Hagerstown). 2008;9(4):382-8. https:// doi.org/10.2459/JCM.0b013e3282f03b90.

42. Ortmann J, Nuesch E, Traupe T, Diehm N, Baumgartner I. Gender is an independent risk factor for distribution pattern and lesion morphology in chronic critical limb ischemia. J Vasc Surg. 2012;55(1): 98-104. https://doi.org/10.1016/j.jvs.2011.07.074.

43. Diehm N, Shang A, Silvestro A, Do DD, Dick F, Schmidli J, et al. Association of cardiovascular risk factors with pattern of lower limb atherosclerosis in 2659 patients undergoing angioplasty. Eur J Vasc Endovasc Surg. 2006;31(1):59-63. https://doi.org/10.1016/j.ejvs. 2005.09.006

44. Gardner AW. Sex differences in claudication pain in subjects with peripheral arterial disease. Med Sci Sports Exerc. 2002;34(11): 1695-8. https://doi.org/10.1249/01.MSS.0000035043.05178.58.

45. Collins TC, Suarez-Almazor M, Bush RL, Petersen NJ. Gender and peripheral arterial disease. J Am Board Fam Med. 2006;19(2):132-40.

46. Krishnamurthy V, Munir K, Rectenwald JE, Mansour A, Hans S, Eliason JL, et al. Contemporary outcomes with percutaneous vascular interventions for peripheral critical limb ischemia in those with and without poly-vascular disease. Vasc Med. 2014;19(6): 491-9. https://doi.org/10.1177/1358863X14552013.

47. Selvin E, Hirsch AT. Contemporary risk factor control and walking dysfunction in individuals with peripheral arterial disease: NHANES 1999-2004. Atherosclerosis. 2008;201(2):425-33. https://doi.org/10.1016/j.atherosclerosis.2008.02.002.

48. Pande RL, Perlstein TS, Beckman JA, Creager MA. Secondary prevention and mortality in peripheral artery disease: National
Health and Nutrition Examination Study, 1999 to 2004. Circulation. 2011;124(1):17-23. https://doi.org/10.1161/ CIRCULATIONAHA.110.003954.

49. Hiatt WR, Regensteiner JG, Hargarten ME, Wolfel EE, Brass EP. Benefit of exercise conditioning for patients with peripheral arterial disease. Circulation. 1990;81(2):602-9.

50. Hiatt WR, Wolfel EE, Meier RH, Regensteiner JG. Superiority of treadmill walking exercise versus strength training for patients with peripheral arterial disease. Implications for the mechanism of the training response. Circulation. 1994;90(4):1866-74.

51. Parmenter BJ, Raymond J, Dinnen P, Singh MA. A systematic review of randomized controlled trials: walking versus alternative exercise prescription as treatment for intermittent claudication. Atherosclerosis. 2011;218(1):1-12. https://doi.org/10.1016/j. atherosclerosis.2011.04.024.

52. Gardner AW, Parker DE, Montgomery PS, Blevins SM. Diabetic women are poor responders to exercise rehabilitation in the treatment of claudication. J Vasc Surg. 2014;59(4):1036-43. https://doi. org/10.1016/j.jvs.2013.10.058.

53. Gardner AW, Parker DE, Montgomery PS, Blevins SM, Nael R, Afaq A. Sex differences in calf muscle hemoglobin oxygen saturation in patients with intermittent claudication. J Vasc Surg. 2009;50(1):77-82. https://doi.org/10.1016/j.jvs.2008.12.065.

54. Gommans LN, Scheltinga MR, van Sambeek MR, Maas AH, Bendermacher BL, Teijink JA. Gender differences following supervised exercise therapy in patients with intermittent claudication. J Vasc Surg. 2015;62(3):681-8. https://doi.org/10.1016/j.jvs.2015. 03.076 .

55. Gardner AW, Montgomery PS, Blevins SM, Parker DE. Gender and ethnic differences in arterial compliance in patients with intermittent claudication. J Vasc Surg. 2010;51(3):610-5. https://doi. org/10.1016/j.jvs.2009.09.059.

56. Jude EB, Eleftheriadou I, Tentolouris N. Peripheral arterial disease in diabetes-a review. Diabet Med. 2010;27(1):4-14. https://doi.org/ 10.1111/j.1464-5491.2009.02866.x.

57. Malgor RD, Alahdab F, Elraiyah TA, Rizvi AZ, Lane MA, Prokop LJ, et al. A systematic review of treatment of intermittent claudication in the lower extremities. J Vasc Surg. 2015;61(3 Suppl):54S73S. https://doi.org/10.1016/j.jvs.2014.12.007.

58. Rowe VL, Weaver FA, Lane JS, Etzioni DA. Racial and ethnic differences in patterns of treatment for acute peripheral arterial disease in the United States, 1998-2006. J Vasc Surg. 2010;51(4 Suppl):21S-6S. https://doi.org/10.1016/j.jvs.2009.09.066.

59. Egorova N, Vouyouka AG, Quin J, Guillerme S, Moskowitz A, Marin M, et al. Analysis of gender-related differences in lower extremity peripheral arterial disease. J Vasc Surg. 2010;51(2):372-8 e1; discussion 8-9. https://doi.org/10.1016/j.jvs.2009.09.006.

60. Carandang R, Seshadri S, Beiser A, Kelly-Hayes M, Kase CS, Kannel WB, et al. Trends in incidence, lifetime risk, severity, and 30 -day mortality of stroke over the past 50 years. JAMA. 2006;296(24):2939-46. https://doi.org/10.1001/jama.296.24.2939.

61. North American Symptomatic Carotid Endarterectomy Trial. Methods, patient characteristics, and progress. Stroke. 1991;22(6): 711-20.

62. Randomised trial of endarterectomy for recently symptomatic carotid stenosis: final results of the MRC European Carotid Surgery Trial (ECST). Lancet. 1998;351(9113):1379-87.

63. Endarterectomy for asymptomatic carotid artery stenosis. Executive Committee for the Asymptomatic Carotid Atherosclerosis Study. JAMA. 1995;273(18):1421-8.

64. Alamowitch S, Eliasziw M, Barnett HJ, North American Symptomatic Carotid Endarterectomy T, Group ASAT, Carotid Endarterectomy Trial G. The risk and benefit of endarterectomy in women with symptomatic internal carotid artery disease. Stroke. 2005;36(1):27-31. https://doi.org/10.1161/01.STR. $0000149622.12636 .1 \mathrm{f}$. 
65. Rothwell PM, Eliasziw M, Gutnikov SA, Warlow CP, Barnett HJ, Carotid Endarterectomy Trialists C. Endarterectomy for symptomatic carotid stenosis in relation to clinical subgroups and timing of surgery. Lancet. 2004;363(9413):915-24. https://doi.org/10.1016/ S0140-6736(04)15785-1.

66. Rothwell PM, Slattery J, Warlow CP. Clinical and angiographic predictors of stroke and death from carotid endarterectomy: systematic review. BMJ. 1997;315(7122):1571-7.

67. Yavas S, Mavioglu L, Kocabeyoglu S, Iscan HZ, Ulus AT, Bayazit $\mathrm{M}$, et al. Is female gender really a risk factor for carotid endarterectomy? Ann Vasc Surg. 2010;24(6):775-85. https://doi.org/10.1016/ j.avsg.2010.02.017.

68. Rockman CB, Castillo J, Adelman MA, Jacobowitz GR, Gagne PJ, Lamparello PJ, et al. Carotid endarterectomy in female patients: are the concerns of the asymptomatic carotid atherosclerosis study valid? J Vasc Surg. 2001;33(2):236-40; discussion 40-1. https://doi. org/10.1067/mva.2001.111804.

69. Vouyouka AG, Egorova NN, Sosunov EA, Moskowitz AJ, Gelijns A, Marin M, et al. Analysis of Florida and New York state hospital discharges suggests that carotid stenting in symptomatic women is associated with significant increase in mortality and perioperative morbidity compared with carotid endarterectomy. J Vasc Surg. 2012;56(2):334-42. https://doi.org/10.1016/j.jvs.2012.01.066.

70. Bisdas T, Egorova N, Moskowitz AJ, Sosunov EA, Marin ML, Faries PL, et al. The impact of gender on in-hospital outcomes after carotid endarterectomy or stenting. Eur J Vasc Endovasc Surg. 2012;44(3):244-50. https://doi.org/10.1016/j.ejvs.2012.06.009.

71. Wann-Hansson C, Hallberg IR, Risberg B, Lundell A, Klevsgard R. Health-related quality of life after revascularization for peripheral arterial occlusive disease: long-term follow-up. J Adv Nurs. 2005;51(3):227-35. https://doi.org/10.1111/j.1365-2648.2005. 03499.x.

72. Dreyer RP, van Zitteren M, Beltrame JF, Fitridge R, Denollet J, Vriens PW, et al. Gender differences in health status and adverse outcomes among patients with peripheral arterial disease. J Am Heart Assoc. 2014;4(1):e000863. https://doi.org/10.1161/JAHA. 114.000863 .

73. Hultgren R, Olofsson P, Wahlberg E. Sex-related differences in outcome after vascular interventions for lower limb ischemia. $\mathrm{J}$ Vasc Surg. 2002;35(3):510-6.

74. McCoach CE, Armstrong EJ, Singh S, Javed U, Anderson D, Yeo $\mathrm{KK}$, et al. Gender-related variation in the clinical presentation and outcomes of critical limb ischemia. Vasc Med. 2013;18(1):19-26. https://doi.org/10.1177/1358863X13475836.

75. AhChong AK, Chiu KM, Wong M, Yip AW. The influence of gender difference on the outcomes of infrainguinal bypass for critical limb ischaemia in Chinese patients. Eur J Vasc Endovasc Surg. 2002;23(2):134-9. https://doi.org/10.1053/ejvs.2001.1564.

76. Abbott WM, Green RM, Matsumoto T, Wheeler JR, Miller N, Veith FJ, et al. Prosthetic above-knee femoropopliteal bypass grafting: results of a multicenter randomized prospective trial. Above-Knee Femoropopliteal Study Group. J Vasc Surg. 1997;25(1):19-28.

77. Ballard JL, Bergan JJ, Singh P, Yonemoto H, Killeen JD. Aortoiliac stent deployment versus surgical reconstruction: analysis of outcome and cost. J Vasc Surg. 1998;28(1):94-101. discussion -3

78. Nguyen LL, Brahmanandam S, Bandyk DF, Belkin M, Clowes AW, Moneta GL, et al. Female gender and oral anticoagulants are associated with wound complications in lower extremity vein bypass: an analysis of 1404 operations for critical limb ischemia. J Vasc Surg. 2007;46(6):1191-7. https://doi.org/10.1016/j.jvs.2007. 07.053 .

79. Eugster T, Gurke L, Obeid T, Stierli P. Infrainguinal arterial reconstruction: female gender as risk factor for outcome. Eur J Vasc Endovasc Surg. 2002;24(3):245-8.

80. Harthun NL, Cheanvechai V, Graham LM, Freischlag JA, Gahtan V. Arterial occlusive disease of the lower extremities: do women differ from men in occurrence of risk factors and response to invasive treatment? J Thorac Cardiovasc Surg. 2004;127(2):318-21. https://doi.org/10.1016/j.jtcvs.2003.10.020.

81. Ballotta E, Gruppo M, Lorenzetti R, Piatto G, DaGiau G, Toniato A. The impact of gender on outcome after infrainguinal arterial reconstructions for peripheral occlusive disease. J Vasc Surg. 2012;56(2):343-52. https://doi.org/10.1016/j.jvs.2012.01.040.

82. Ankle Brachial Index C, Fowkes FG, Murray GD, Butcher I, Heald CL, Lee RJ, et al. Ankle brachial index combined with Framingham Risk Score to predict cardiovascular events and mortality: a metaanalysis. JAMA. 2008;300(2):197-208. https://doi.org/10.1001/ jama.300.2.197.

83. Hussain MA, Lindsay TF, Mamdani M, Wang X, Verma S, AlOmran M. Sex differences in the outcomes of peripheral arterial disease: a population-based cohort study. CMAJ Open. 2016;4(1): E124-31. https://doi.org/10.9778/cmajo.20150107.

84. Riess HC, Debus ES, Heidemann F, Stoberock K, Grundmann RT, Behrendt CA. Gender differences in endovascular treatment of infrainguinal peripheral artery disease. Vasa. 2017;46(4):296-303. https://doi.org/10.1024/0301-1526/a000634.

85. Lo RC, Bensley RP, Dahlberg SE, Matyal R, Hamdan AD, Wyers $\mathrm{M}$, et al. Presentation, treatment, and outcome differences between men and women undergoing revascularization or amputation for lower extremity peripheral arterial disease. J Vasc Surg. 2014;59(2):409-18 e3. https://doi.org/10.1016/j.jvs.2013.07.114. 